\title{
Applying Design Thinking Process in Student's Project: A case of EGF Products
}

\author{
Chun-Ming Yang ${ }^{1, *}$, and Hong-Thien T. Man ${ }^{1}$ \\ ${ }^{1}$ Industrial Design Department, Ming Chi University of Technology, Taiwan
}

\begin{abstract}
Design thinking process is best known as an effective, humancentred approach to more creative problem solving. This method has been applied as an innovative solution generation technique not only for designers but in other disciplines as well. While Epidermal Growth Factor (EGF) is an important growth factor in human body. It plays a crucial role in recent biological researches for many health-care applications. This study incorporated the design thinking process in EGF application products, aims to encourage student designers to embark on this freshly new problem-solving methodology in biological application, and hope to help introduce new medical products in daily life. Two cases as the results came out from the hands-on class project were also presented.
\end{abstract}

\section{Introduction}

Design Thinking has been growing as a central point in the contemporary design world with a variety of applications not only focusing on just a single product but more becoming a methodology to practice for innovations. From a large scale of the design industry, this human-centred approach results in innovative impacts, to a smaller scale of academic environments, applying design thinking also helps design students build up with creative confidence and transform them into design thinkers [1].

In the journal "Notes on the Evolution of Design Thinking: A Work in Progress", Craig M. Vogel emphasized on the progression of design thinking within multidisciplinary programs that could bring out a new model for innovation not just in universities but companies to approach all of the unmet global human need [2]. Design Thinking has been taught in successful design education at d.school, the Institute of Design at Stanford University as a methodology for innovating routinely [3] with feasibility, viability, and desirability to approach the real needs and desires of the human. Roger Martin also believed that design thinking could bring potential effects on education when design thinking was about the mental processes through a project-based workflow for problem-solving solutions [4]. Moreover, Design Thinking might help students become empowered agents on their own way of self-developing because of possessing both the tools and the confidence to change the world [5].

There are three typical spaces in Design Thinking Process: inspiration, ideation, and implementation [6] while Carroll and other researchers [5] proposed a conceptual

\footnotetext{
* Corresponding author: cmyang@mail.mcut.edu.tw
} 
framework with six key steps of Design Thinking Process: Understand, Observe, Point of View, Ideate, Prototype, and Test. This study integrated the three-space model with six-step framework to introduce a Design Thinking process to design student with hands-on practice within a industrial design class project. This assignment is designed to bring the fundamental concept of Design Thinking to unlock students' potential abilities and creative confidence. This paper begins with reviewing relevant literature, followed by Design Thinking process conducted in this class project and then demonstrating results with the cases from the EGF application project.

\section{Literature Reviews}

Design Thinking has a rich history in the academic environment from Bauhaus time to Stanford's d.school. And one of the reasons that coined Design Thinking as a valued methodology is human-centeredness. In 1955, Dreyfuss also expressed the idea of humancentred approach in his book, Designing for People [2]. Human-centeredness is not just about emerging field of human factors and ergonomics but needs for logical approaches to produce innovative solutions by focusing on making people the source of inspiration and direction for solving design challenges [5]. Design Thinking Process is human-centred, not technological or business-centred, and about the idea "need-finding" [7].

In the book "The Design of Everyday Things" by Don Norman, the human-centred design process was introduced with four different activities: Observation, Ideation, Prototyping, and Testing. These four activities are iterative to get closer to the desired solution [8]. Tim Brown in his book "Change by Design" also pointed out three mutual elements, which could bring success to any design program: insight, observation, and empathy [1]. Carroll and other researchers mentioned that empathy, which comes from observing, is the intellectual identification of the feelings and thoughts of others [5]. The empathy could enable design thinkers to uncover people's deep insights and implicit needs. And with empathy, designers could stand in others' shoes to connect with the people they observed fundamentally [1]. For that reason, prototypes and drawings, scenario design, storytelling, and role-playing are methods to bring potential solutions back into an imagined situation to address users' experience and emotional response for useful feedbacks and an idea forward [1]. Especially, the culture of prototyping is really important in Design Thinking Process when it focuses on being highly experimental to engage people with artifacts for a better solution [5].

Carroll and other researchers believed that collaboration is essential to Design Thinking Process [5]. The collaborative process in a class project was influenced by students' willingness to listen to other's ideas to take risks and to share their ideas with others. The ability to work collaboratively is also one of the important factors in a design thinker's personality [9]. The best design thinkers need to work along together with other disciplines to collaborate their own significant experience. Instead of working only with your own knowledge or background, a problem or quest would be described on an open and innovative site so that designers could get help from the creative minds of all over the world to solve that problem or quest [3].

One of the important spaces in Design Thinking Process is Ideation - the process of generating ideas to approach potential solutions [9]. There has been an increasing attention on developing more effective methods for idea generation. However, among many methods such as Brain-sketching, C-Sketch, 6-3-5, and Gallery Method [10], C-Sketch is considered as a progressive idea generation method, especially in design related fields. C-Sketch Method, a.k.a. Collaborative Sketching, is shown to be more effective in performing the quality and variety of designs (Kulkarni et al., 2001). Design Thinking Process with CSketch as an idea generation tool could encourage an environment to cut through traditional 
structure and mindset barrier to create an innovative mixture of new ideas. Responsibility for the final outcome is not on any person but from the team's contribution, so there will be no "my idea" in a multidisciplinary team. Collaboration, therefore works much more effective when team members are from different backgrounds or perspectives (Kelly, 2013).

\section{Process \& Methods}

This research generated three spaces in design thinking process (Brown \& Wyatt, 2010) (inspiration, ideation, and implementation) with six design thinking phases proposed by Carroll et al. (2010) (understand, observe, point of view, ideate, prototype, and test) to develop a systematic framework for solving design problem. There were different creativity activities and tools introduced as hands-on practices in different phases in order to help students approach design-thinking concept and achieve specific tasks in each phase.

In Phase 1 - Understand, students conducted pre-research with data collection and presentation to the expert in order to understand the fundamental relevant knowledge. In Phase 2 - Observe, students were required to do a market survey to comprehend deeper customers' behaviors and needs as well as contemporary technologies and products on the commercial market. In Phase 3 - Point of View, students with data analyzing figured out the customers' needs as well as narrowing down the design problem. In Phase 4 - Ideate, students were instructed to use a various collection of hands-on practices with creativity tools such as: Lotus Blossom Method, C-Sketch, AEIOU \& 5W1H, Scenario \& Storytelling, to diverge and develop conceptual idea solutions. Finally with Phase 5 - Prototype and Phase 6 - Test, students were required to come out either virtual or physical prototype for testing to help students ensure if their design solutions could meet customers' needs. Figure 1 demonstrates the framework of this research, which is based on three main spaces of design thinking:

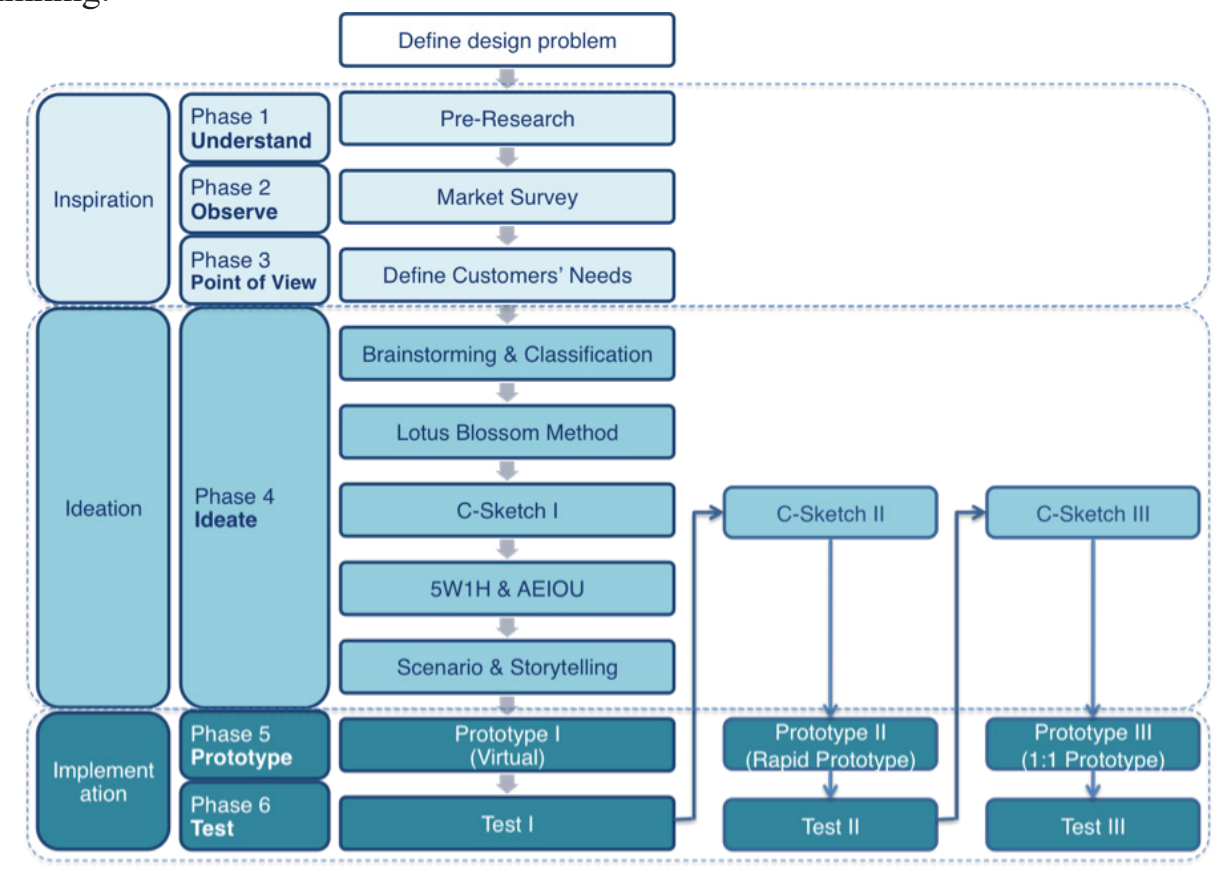

Fig. 1. Framework of this study

\subsection{Phase 1: Understand}


After the design problem had been assigned, students were required to (1) conduct a research for fundamental knowledge based on three questions: What is it? What can it help? Is there any application in our daily life? So the students could get the general comprehension about the technology with its background as well as the limitations; (2) present the pre-research before an expert in that industry for a deeper understanding of the problem.

\subsection{Phase 2: Observe}

With the fundamental understanding from Phase 1, students conducted a market survey with a quick field trip to several commercial supermarkets in order to ensure if there is any application with that technology available on the real market. Moreover, they interviewed some potential customers to understand their using behaviours. This was also one of the important characteristics of design thinking: human-centred approach.

\subsection{Phase 3: Point of view}

Students analyzed the data from two previous phases to narrow down the design problem and define the customers' needs.

\subsection{Phase 4: Ideate}

\subsubsection{Brainstorming \& Classification}

After conducting the market survey, students were asked to write down all keywords relating to products, technologies in the industry on post-it notes. After that, they categorized them in groups of issues (Figure 2). This activity helped students focus on the potential group of issues, which could meet the customers' needs and be applied in the industry.

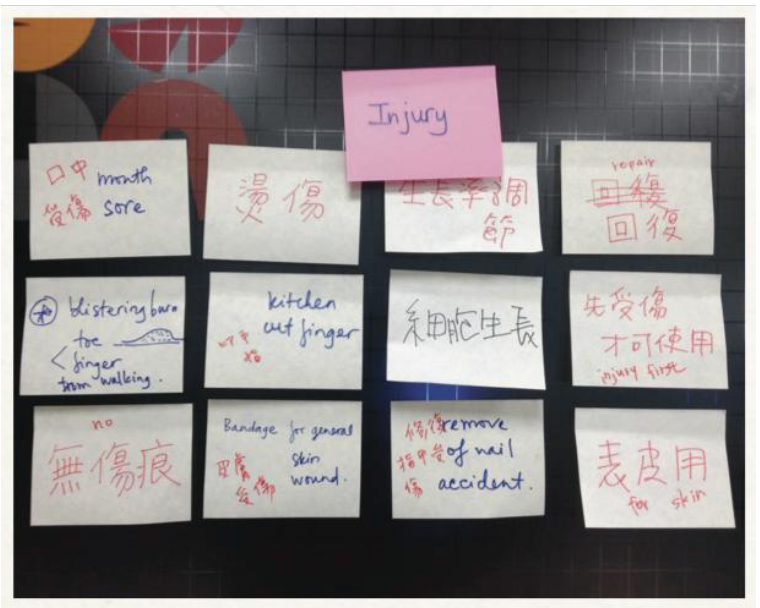

Fig. 2. Post-it notes with keywords and issue groupings 


\subsubsection{Lotus Blossom Brainstorming Method}

Students set design topic in the centre of Lotus Blossom Map, and then fill the first layer of boxes with main keywords from the previous phase (3.4.1). Those main keywords in the first layer of boxes would be set as main topics in the centre of the second layer for divergence. Following those new central keywords, students figured out more keywords to expand the map until it was completed (Figure 3). Finally, the convergence of the Lotus Blossom Map would be started from the outmost layer towards the centre. With the central keywords of each layer, two other keywords would be chosen for the idea combinations. There would be 8 idea combinations from the final map. They would be written in the format: "Design topic $=$ Keyword $1+$ Keyword $2+$ Keyword $3+\ldots+$ Keyword n." Lotus Blossom Brainstorming Method could help students generate a much broader collection of different ideas in a free-flowing and impulsive way (Chen, Yang \& Lai, 2016).

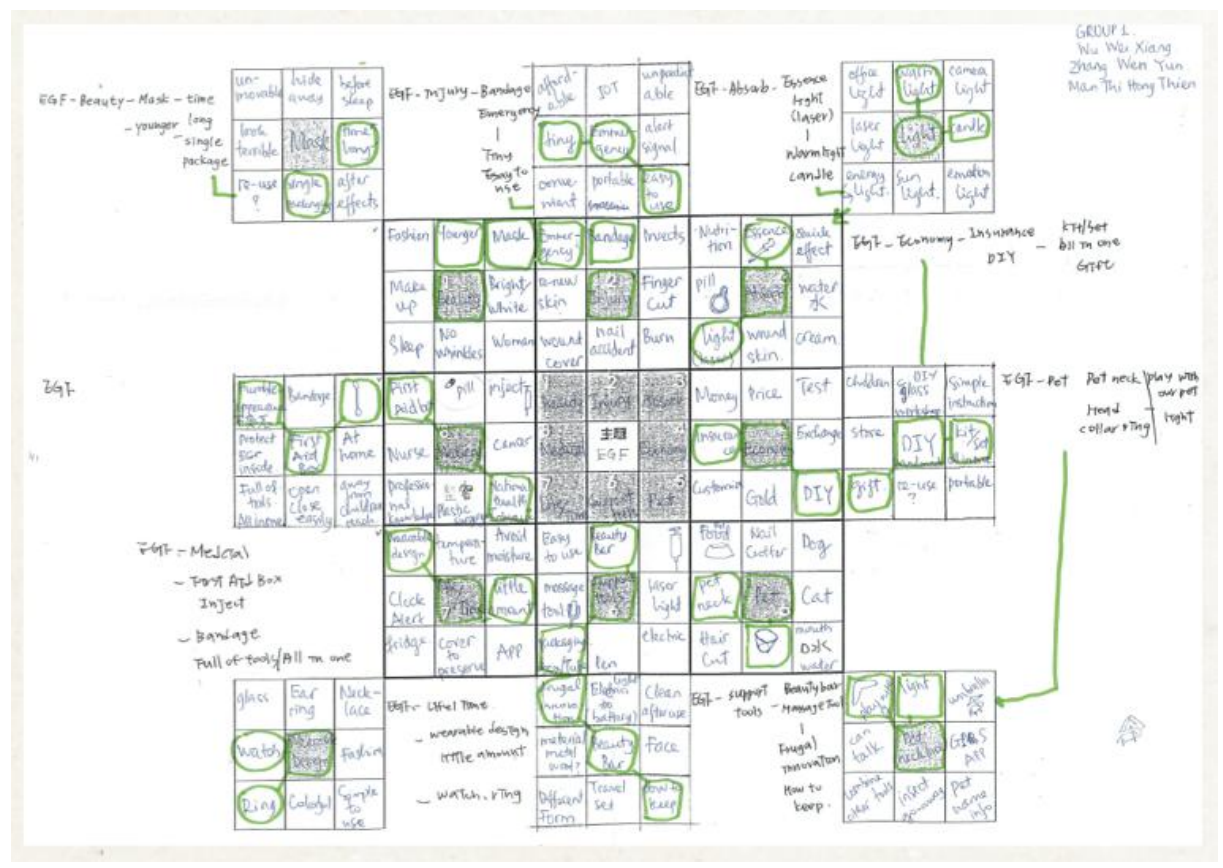

Fig. 3. Lotus Blossom Brainstorming Map

\subsubsection{Collaborative Sketch (C-Sketch)}

From the idea combinations got in the previous phase (3.4.2), students would write down that idea combination on the top of the sketch paper and performed a three-round collaborative sketching. (1) The group conducted the first round to select the most potential concept for proposal with experts' discussion to dig into a deeper level on technical solution of the conceptual idea. (2) Getting the experts' feedbacks from the first round, students continued on developing the conceptual idea and proposed again for the second round of experts' discussion. (3) In the final round, students focused on finishing the conceptual idea according to the second round feedbacks from experts. Collaborative Sketch could help students generate conceptual design solutions in a technological way, which could meet customers' needs. Moreover, sketching helps conceptual design solutions visualized for much dynamic group discussion and idea generation [11]. 


\subsubsection{W1H \& AEIOU}

From the conceptual idea chosen in the first round of C-Sketch (3.4.3), students would use $5 \mathrm{~W} 1 \mathrm{H}$ (standing for Who, What, When, Where, Why, and How) and AEIOU (standing for Activities, Environments, Interactions, Objects, and Users) methods to define the environment, target customers, and activities when using the products etc. These two methods incorporated with Lotus Blossom Map and C-Sketch Method were to help establish meaningful and appropriate design concepts to potential customers [12]. Moreover, these methods also helped the conceptual idea solutions more detailed, completed, and constructive for the later phase of scenario-based design.

\subsubsection{Scenario \& Storytelling}

From the potential customers created in the previous phase (3.4.4), students developed the personas with more detailed characteristics (name, gender, occupation, education, hobby, and personality). The scenario framework was also created with a brief description (who, where, what, and when). And then students developed storyboards to visually establish the potential persona's interaction with the conceptual design solution. Scenario Design \& Storytelling play important roles in developing the design concepts in which human-centred approach was focused [12].

\subsection{Phase 5: Prototype}

Prototyping is an essential phase of design thinking even if it is created virtually or physically. The power of prototyping is to generate results faster because the faster a designer make an idea tangible, the sooner he/she would be able to evaluate it, refine it for a better solution [1]. This phase was conducted with three times: (1) Students were asked to create a virtual prototype with sketching or 3D modelling images. (2) After the discussion with experts, students made a rapid prototype usually with paper at the scale 1:1 to ensure whether the form would be suitable for the function and applied technology. (3) Finally, the prototype would be refined again with details, usage instructions, and real material, still at the scale 1:1, to improve the better image of conceptual solutions. Prototyping encouraged students to interact with their own conceptual solutions to make sure if the design meets potential customers' needs.

\subsection{Phase 6: Test}

Following three times of prototyping, there were also three times of testing. (1) The first time was to check if the conceptual sketches from phase 1.4.3 could be developed after the discussion with experts about the possibilities and limitations. (2) Getting the experts' advice from the first round, the design was developed and improved with a rapid prototype at the scale 1:1. In this second testing, the conceptual design would be check if it could be developed in the real commercial market. (3) At the final testing, with the feedbacks from experts' second testing, the conceptual product at the scale 1:1 with real material and completed packaging design were ready to persuade the potential customers' needs. Testing ensures that students learned what would be possible and that might not work for target customers. That required them to go back to their prototype and modify it based on experts' feedbacks [5]. 


\section{Results}

This study, incorporated the design thinking process in epidermal growth factors (EGF) application products as the design problem, aims to encourage student designers to embark on this new problem-solving approach to introducing solutions for EGF application. The research was conducted during ten weeks of the Industrial Design course in the first semester of the 2016-2017 academic years with first-year master students at the Department of Industrial Design in Ming Chi University of Technology as the participants. There were 12 students who were divided into four groups and instructed by one industrial design expert and one biochemistry expert. The results of this applying design thinking process were displayed as the flow of previous process and methods above.

\subsection{Phase 1: Understand}

Students conducted a research for fundamental knowledge about EGF as well as presented their pre-research with the biochemistry expert (Figure 4). The experts would discuss more on their research to help students understand deeper the reality of this technology and industry, such as: EGF history, production method, applicable wounds, economic cost and value, and impacts in life, etc.

\subsection{Phase 2: Observe}

Students conducted a market survey to learn if there is any application with EGF technology available on the commercial market, especially in beauty care and wound care products. With human-centred spirit, they also interviewed potential customers to understand their behaviours in using skincare products. This observation encourages students to develop a sense of empathy [5].

\subsection{Phase 3: Point of view}

After students learned from Phase 1. Understand and Phase 2. Observe they developed a point of view that focused on potential customers' needs and insights [5]. In this case with EGF applications, the design problem was narrowed down through their research: (1) there were no skincare or wound care product with EGF application technology in the commercial market, (2) how does EGF work when applying onto the wounds as a healing factor?

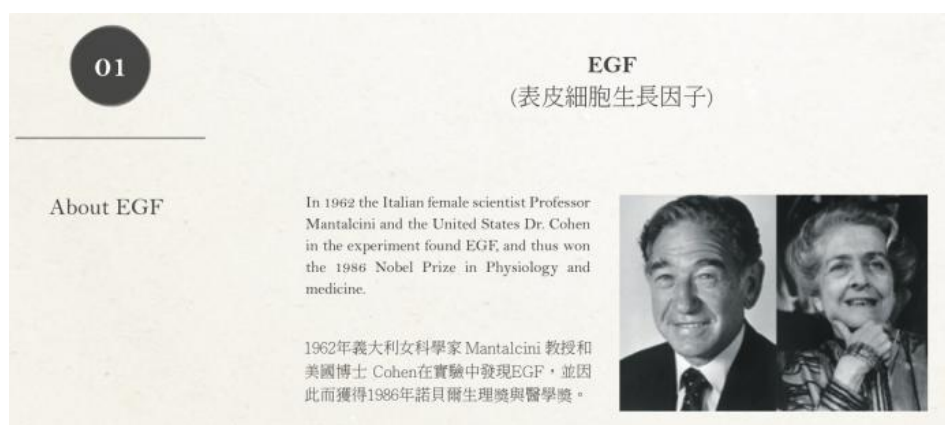

Fig. 4. One slide from students' pre-research about EGF before discussion with experts. 


\subsection{Phase 4: Ideate}

\subsubsection{Brainstorming \& Classification}

With new knowledge after the market survey and defined design problem from previous steps, students wrote down all relevant keywords on post-it papers and categorized into groups. They came out totally 33 keywords and grouped into 4 themes: Economy, Absorb, Injury, and Beauty (Table 1).

Table 1. Categorized 33 keywords into 4 themes of ideas

\begin{tabular}{|l|l|l|l|}
\hline Economy (5) & Absorb (3) & Injury (12) & Beauty (13) \\
\hline Economy & Absorb & Burn & Repair \\
Expiration & Metabolism & Repair & Moist \\
date & Osmosis & For skin & Beauty \\
Different & & No scar & Woman \\
species & & Mouth sore & Elasticity \\
Keep & & Cut finger & Anti aging \\
something & & Cell growth & Essence \\
High price & & Injury first & Reduce the wrinkle \\
& & Relative growth rate & Dark lips brightening \\
& & Remove of nail & Support instrument \\
& & accident & Bandage for facial spots \\
& & Bandage for general & Eye dark circles \\
& & skin wound & brightening \\
& & Blistering burn (toe, & Skin on head hair care \\
& & finger) from walking & after being dyed \\
\hline
\end{tabular}

\subsubsection{Lotus Blossom Brainstorming Method}

Students set EGF - the design topic - in the central box of Lotus Blossom Map, then fill 4 main keywords from the previous categorized groups (Economy, Absorb, Injury, and Beauty). They need 4 more to complete the very first layer of the 9-window-map, so they added 4 more keywords: Medical, Life/Time, Support Tools, and Pet from their previous brainstorming phase. These 8 keywords would be the central keywords of the second level 9-window-map to be continued for divergence. After fulfilling the whole map of 3 level of 9-window-map, they came out 8 idea combinations (Figure 5a \& 5b).

\subsubsection{Collaborative Sketch (C-Sketch)}

From 8 idea combinations got from the previous phase (4.4.2), students performed a threeround collaborative sketching with 6 idea combinations. After finishing 2 rounds, they came out 42 sketches ( 7 sketches for each idea combinations) in which they chose 6 final conceptual sketches for the next phase of Design Thinking Process. Figure $6 \mathrm{a} \& 6 \mathrm{~b}$ would show the process of Collaborative Sketch through 3 rounds of one example of an idea combination: EGF $=$ Economy + DIY + Insurance + All in One + Gift. 


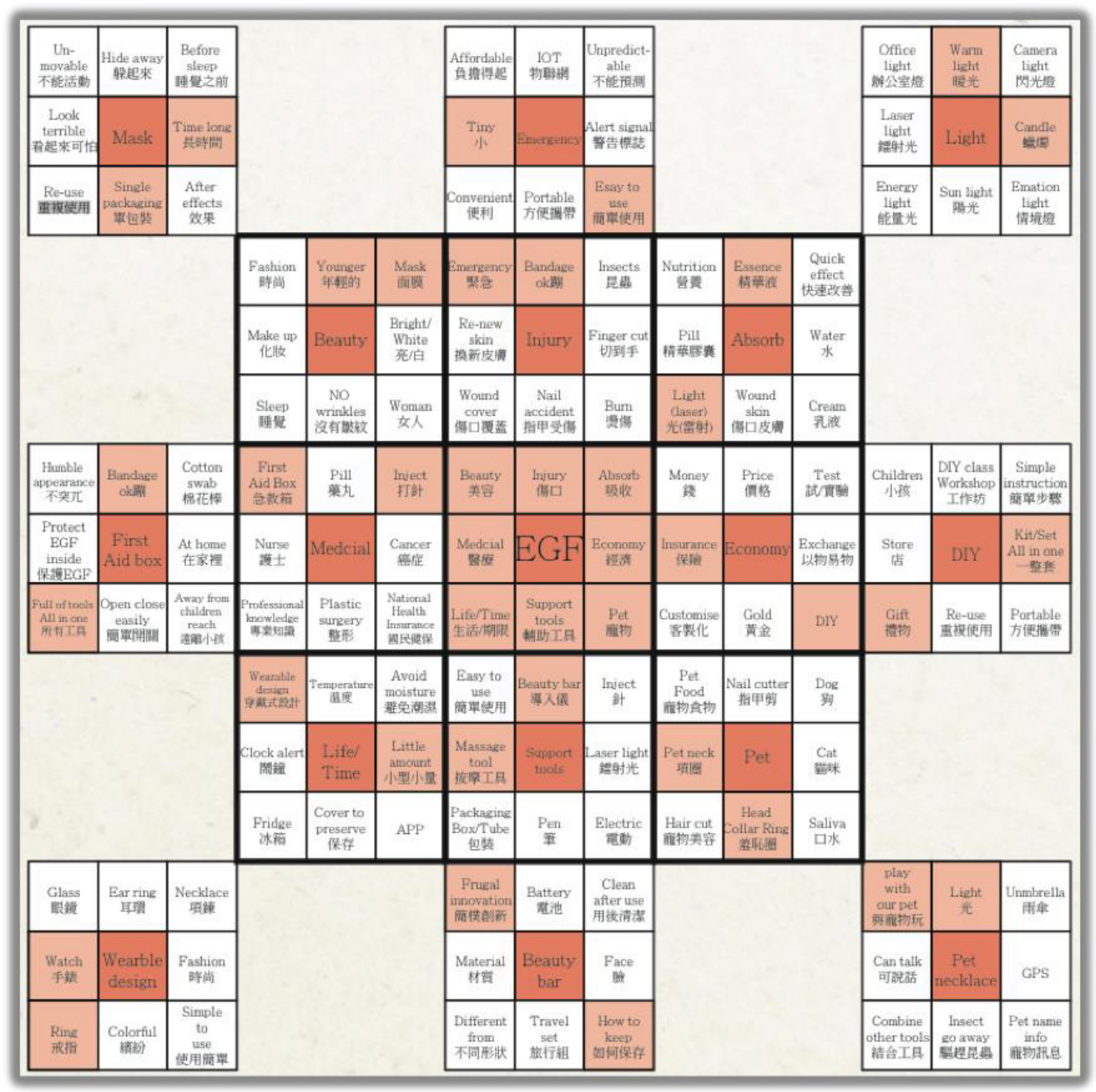

Fig. 5a. Fulfilling the whole Lotus Blossom Map

\begin{tabular}{|c|c|c|c|c|c|c|c|c|}
\hline \multirow[t]{2}{*}{ (1) Beauty } & $\begin{array}{l}\text { Mask } \\
\text { 面膜 }\end{array}$ & $\begin{array}{l}\text { Time long } \\
\text { 長時間 }\end{array}$ & (4) Injury & $\begin{array}{l}\text { Bandage } \\
\text { ok政 }\end{array}$ & $\begin{array}{l}\text { Tiny } \\
\text { 小 }\end{array}$ & (7) Absorb & $\begin{array}{l}\text { Essence } \\
\text { 精華液 }\end{array}$ & $\begin{array}{l}\text { Warm } \\
\text { light } \\
\text { 暖光 }\end{array}$ \\
\hline & $\begin{array}{l}\text { Younger } \\
\text { 年輕的 }\end{array}$ & $\begin{array}{l}\text { Single } \\
\text { packaging } \\
\text { 單包裝 }\end{array}$ & & $\begin{array}{l}\text { Emergency } \\
\text { 緊急 }\end{array}$ & $\begin{array}{l}\text { Esay to } \\
\text { use } \\
\text { 簡單使用 }\end{array}$ & & $\begin{array}{l}\text { Light } \\
\text { (laser) } \\
\text { 光(雷射) }\end{array}$ & $\begin{array}{l}\text { Candle } \\
\text { 蜮㯰 }\end{array}$ \\
\hline \multirow[t]{2}{*}{$\begin{array}{l}\text { (2) Life } \\
\text { Time }\end{array}$} & $\begin{array}{l}\text { Wearable } \\
\text { design } \\
\text { 穿戴式設計 }\end{array}$ & $\begin{array}{l}\text { Watch } \\
\text { 手錶 }\end{array}$ & $\begin{array}{l}\text { (5) Support } \\
\text { tools }\end{array}$ & $\begin{array}{l}\text { Beauty bar } \\
\text { 道入儀 }\end{array}$ & $\begin{array}{l}\text { Frugal } \\
\text { innovation } \\
\text { 簡椦創新 }\end{array}$ & (8) Pet & $\begin{array}{l}\text { Pet neck } \\
\text { 項圈 }\end{array}$ & $\begin{array}{l}\text { play } \\
\text { with } \\
\text { our pet } \\
\text { 與㟫物玩 }\end{array}$ \\
\hline & $\begin{array}{l}\text { Little } \\
\text { amount } \\
\text { 小型小量 }\end{array}$ & $\begin{array}{l}\text { Ring } \\
\text { 娀指 }\end{array}$ & & $\begin{array}{l}\text { Massage } \\
\text { tool } \\
\text { 按摩工具 }\end{array}$ & $\begin{array}{l}\text { How to } \\
\text { keep } \\
\text { 如何保存 }\end{array}$ & & $\begin{array}{l}\text { Head } \\
\text { Collar Ring } \\
\text { 羞恥圈 }\end{array}$ & $\begin{array}{l}\text { Light } \\
\text { 光 }\end{array}$ \\
\hline \multirow[t]{2}{*}{ (3) Medcial } & $\begin{array}{l}\text { First } \\
\text { Aid Box } \\
\text { 急救箱 }\end{array}$ & $\begin{array}{l}\text { Bandage } \\
\text { ok䠒 }\end{array}$ & (6) Economy & DIY & $\begin{array}{l}\text { Kit/Set } \\
\text { All in one } \\
\text { 一整萑 }\end{array}$ & & & \\
\hline & $\begin{array}{l}\text { Inject } \\
\text { 打針 }\end{array}$ & $\begin{array}{l}\text { Full of tools } \\
\text { All in one } \\
\text { 所有工具 }\end{array}$ & & $\begin{array}{l}\text { Insurance } \\
\text { 保險 }\end{array}$ & $\begin{array}{l}\text { Gift } \\
\text { 禮物 }\end{array}$ & & & \\
\hline
\end{tabular}

Fig. 5b. 8 idea combinations from Lotus Blossom Brainstorming Methods 


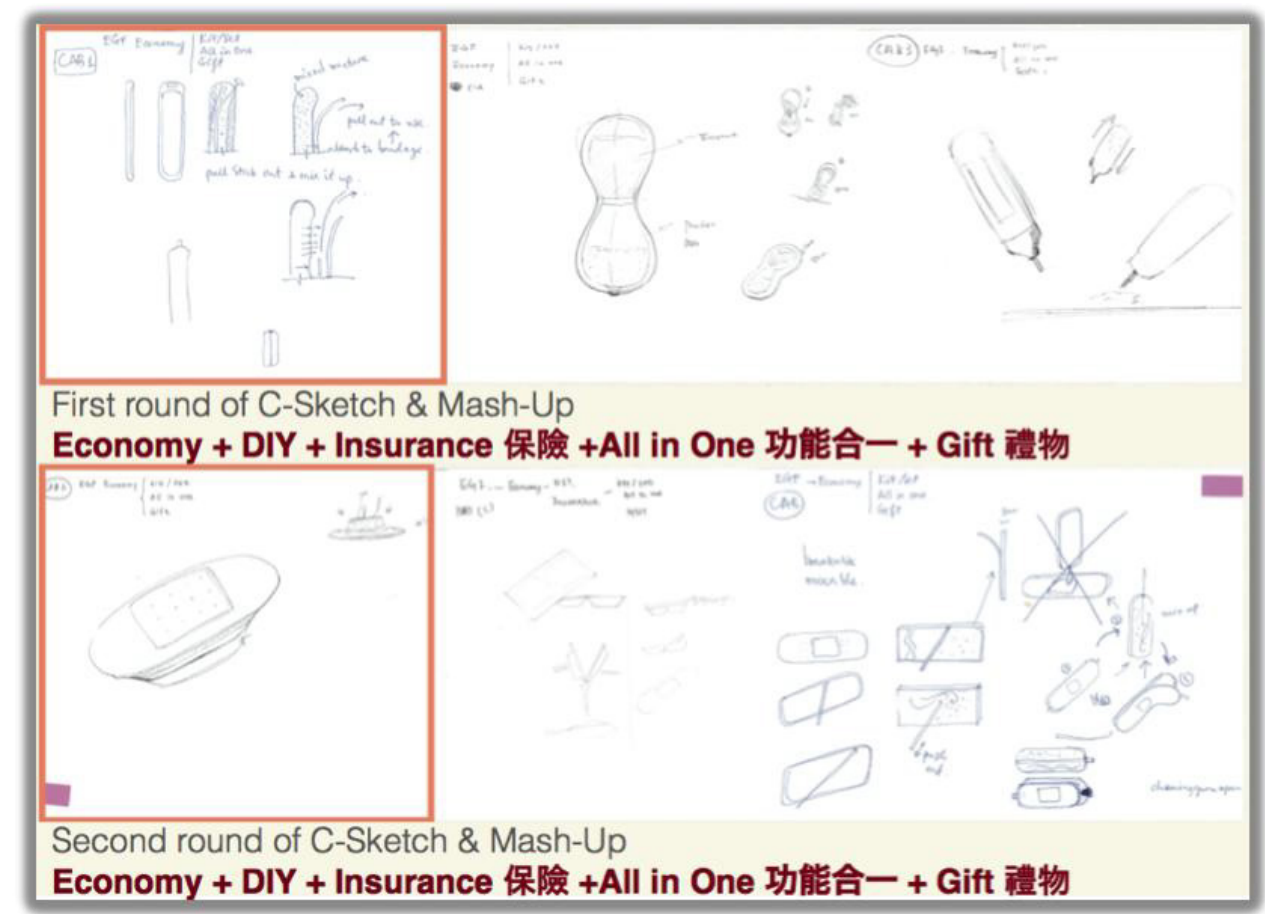

Fig. 6a. The first round and the second round of C-Sketch

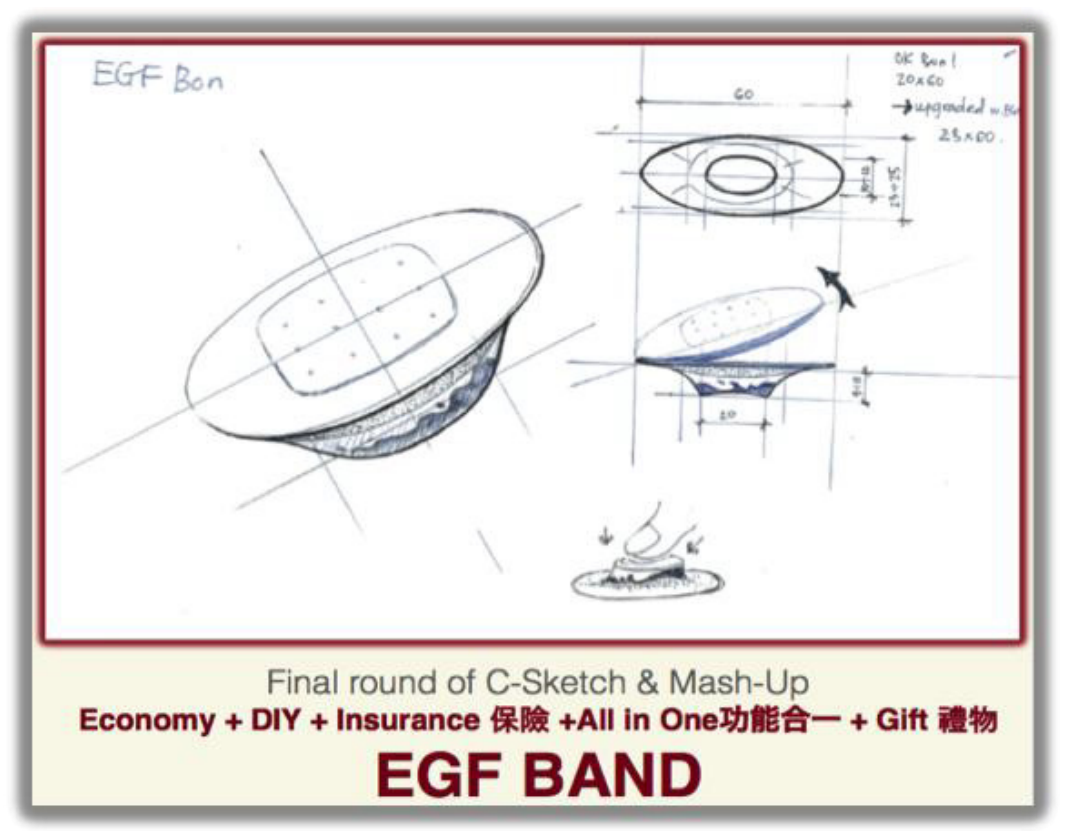

Fig. 6b. The final round of C-Sketch

\subsubsection{W1H \& AEIOU}

From the final conceptual idea from the three-round collaborative sketching (4.4.3), with the case EGF Band, students used 5W1H and AEIOU to get the detailed and imaginative approach to potential customers who might use the product in some situations. In this case, 
these methods could help students understand more about the possibility and convenience of using EGF Band with a purpose of an intensively fast healing solution (Figure 7).

\subsubsection{Scenario \& Storytelling}

With detailed and contributive information from the previous phase (4.4.4), students carved more clearly with the personas that would be potential customers of their product design by developing storyboards visually (Figure 7). In this case with EGF Band, they described the scenario in which a teenager named Lufy (who) got into a fight at school (where) after class (when) then used EGF Band (what) to heal the wound on his face (why).

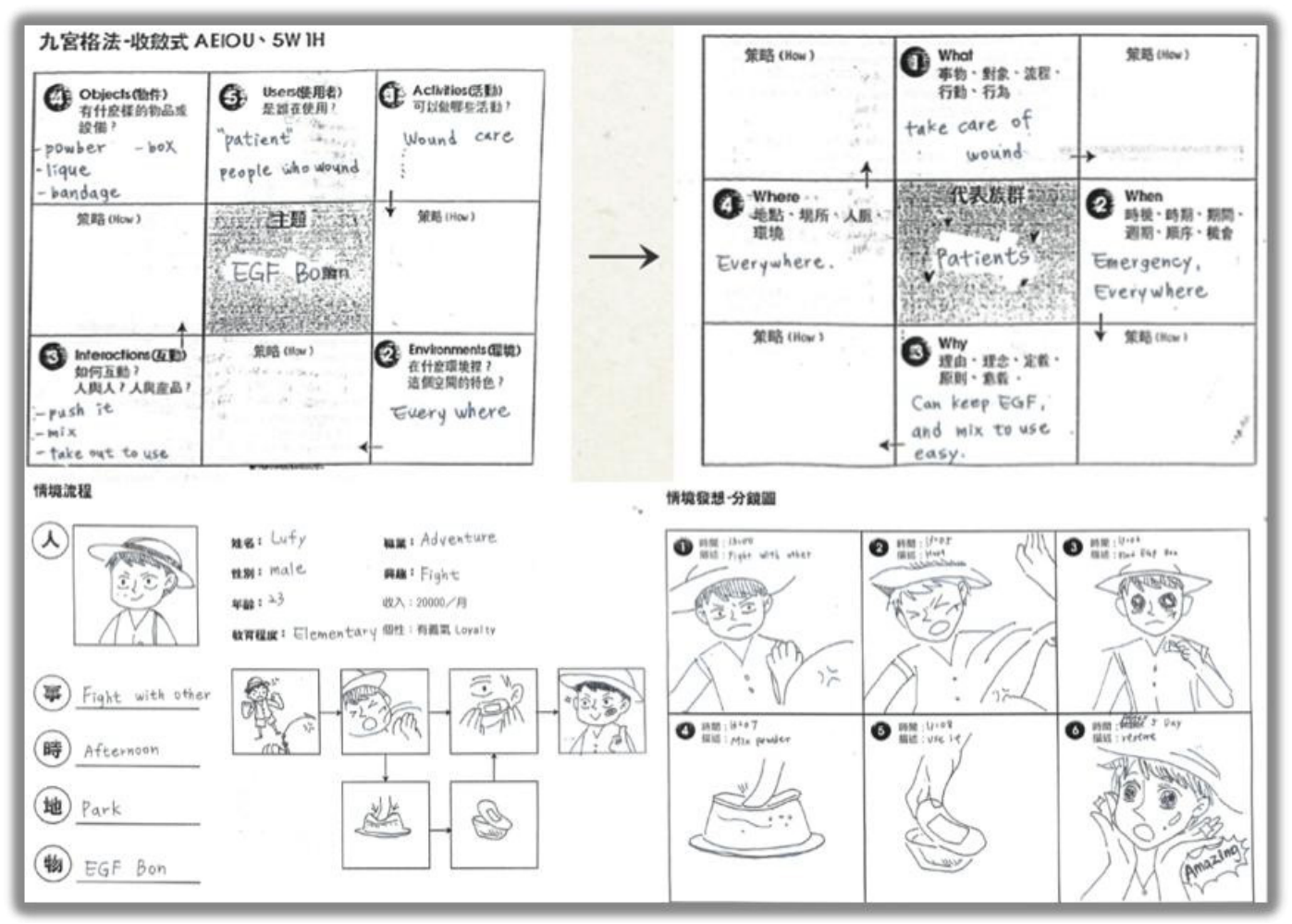

Fig. 7. Using 5W1H \& AEIOU with Scenario \& Storytelling

\subsection{Phase 5: Prototype}

Students conducted this phase three times to refine the conceptual product whether it could fulfil the customers' needs or requirements as a medical daily product which is easy to use and bring along. Figure 8 would show more about the EGF Band with virtual prototype and $1: 1$ one also.

\subsection{Phase 6: Test}

Students took testing with expert's feedbacks by presentations through three times to ensure the possibility of conceptual product EGF Band that was persuaded as a both user-andenvironment-friendly product (Figure 9). 

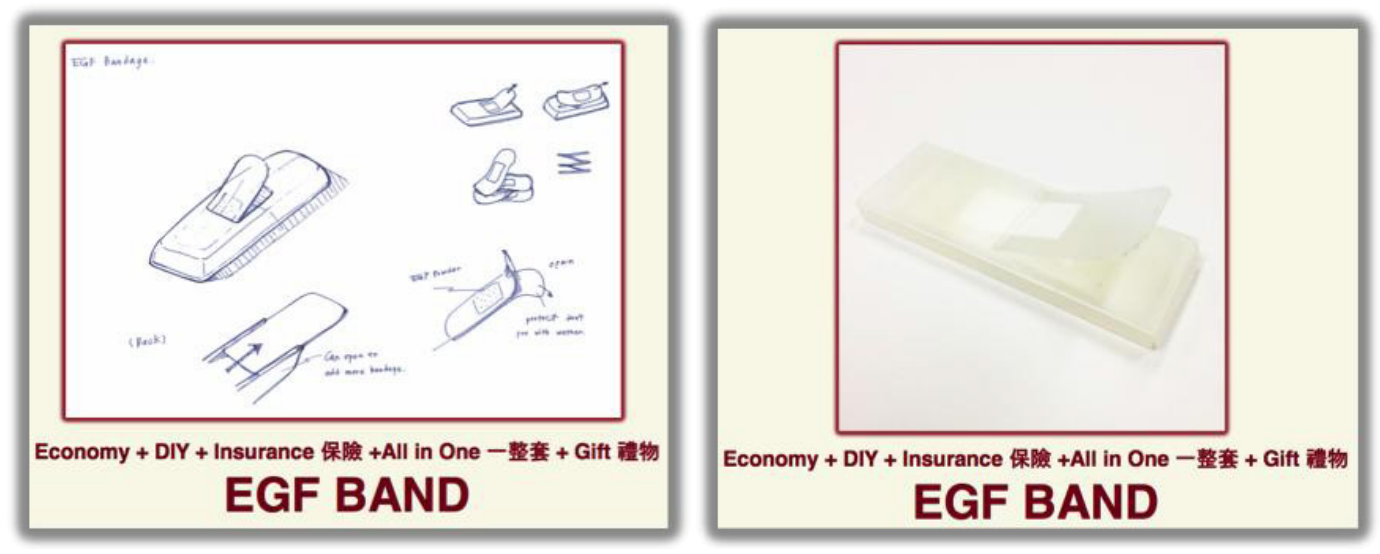

Fig. 8. Virtual prototype (2D sketching) and 1:1 prototype (3D model)

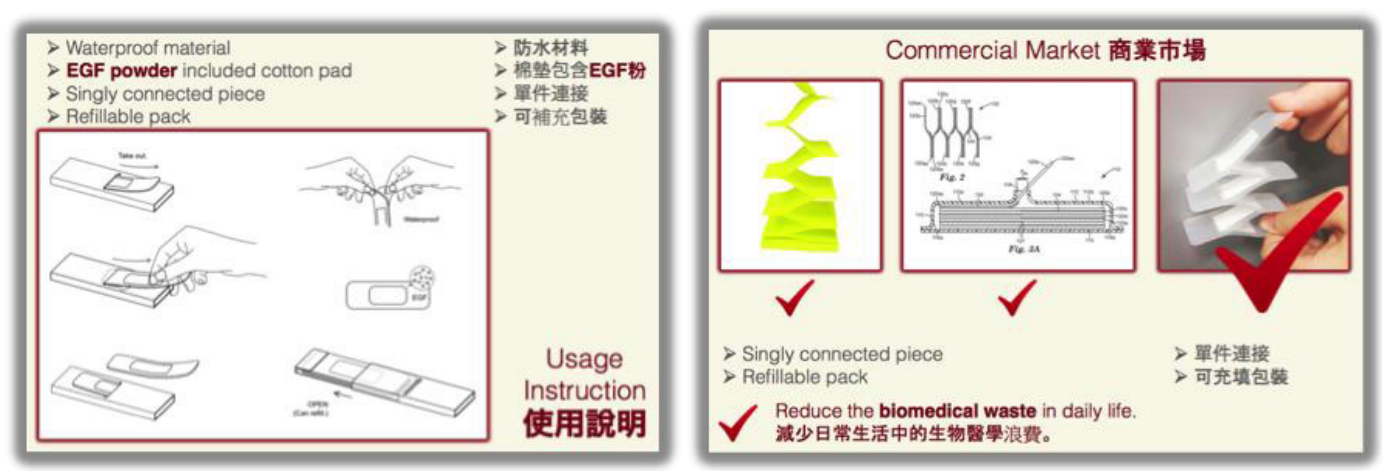

Fig. 9. Testing the conceptual product by presentation with expert

\section{Discussion \& Conclusion}

This design thinking process was conducted with six-phase framework that was proposed by group researchers of Carroll: Understand, Observe, Point of View, Ideate, Prototype, and Test [5]. In spite of time constraint, students were instructed to follow completely the process with some idea combinations to come out conceptual solutions, some of which were commented by experts as good ideas to develop in reality for the design problem. With EGF Band, EGF Nurse was also a potentially conceptual design, which the group of students chose to develop until the last phase (Figure 10). However, these conceptual designs still need to be considered with more factors (trial manufacturing, material costing, user testing, and business marketing, etc.) for higher potential products.

In conclusion, this study demonstrated how we applied three spaces in design-thinking process: inspiration, ideation, and implementation) [6] with six design thinking phases proposed by group researchers of Carroll [5] (understand, observe, point of view, ideate, prototype, and test) to generate a systematic framework within the environment of an industrial design class project. We believed with this new framework, design students could learn more about the human-centred approach, collaborative design, and divergent and convergent thinking to achieve new experiences in solving a design problem. This study with different creativity activities and tools instructed as hands-on practices in separate phases could help design students build up their creative confidence and encourage them to become design thinkers in future. 

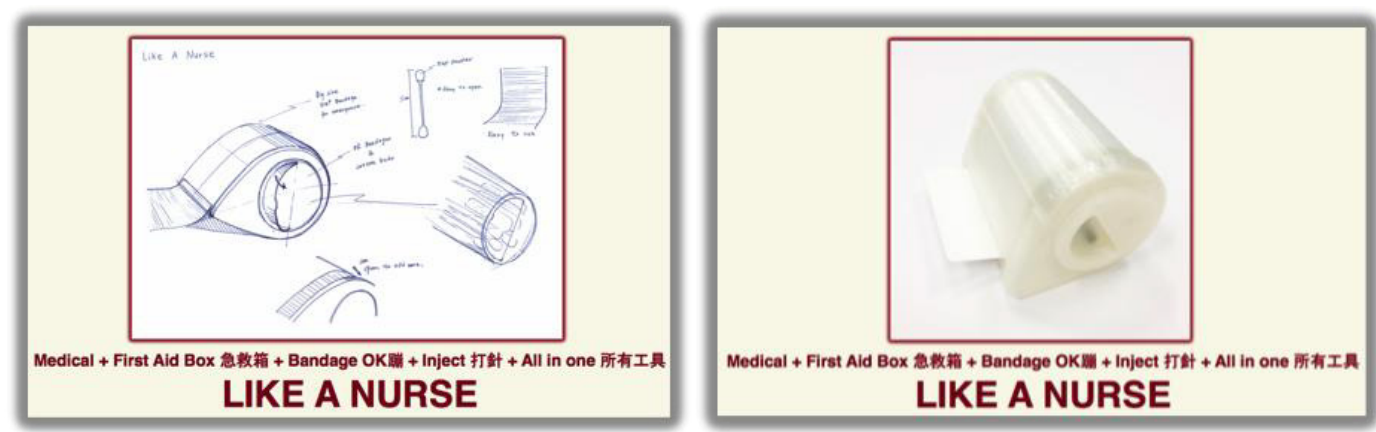

Fig. 10. Another conceptual design in the same Design Thinking Process

Acknowledgments: The authors are grateful for support of the Ministry of Science and Technology, R.O.C. under grants MOST105-2221-E-131-024- and MOST106-2221-E-131-017-. The authors also gratefully acknowledge the helpful comments and suggestions of the reviewers, which have improved the presentation. Furthermore, the authors are grateful for Professor Liang-Jung Chien and all students, especially Wen-Yun Zhang and Wei-Xiang Wu, participated in the design thinking workshop in Industrial Design Course of Fall September, 2016, Industrial Design Department, Ming Chi University of Technology, Taiwan.

\section{References}

1. T. Brown, Change by Design: How Design Thinking Transforms Organizations and Inspires Innovation (2009)

2. C. M. Vogel, DMR, 20, 15-27 (2010)

3. T. Kelly, D. Kelly, Creative Confidence (2013)

4. D. Dunne, R. Martin, AMLE, 5, 512-523 (2006)

5. M. Carroll, S. Goldman, L. Britos, J. Koh, A. Royalty, M. Hornstein, IJADE, 29, 37-53 (2010)

6. T. Brown, J. Wyatt, SSIR, 8, 30-35 (2010)

7. M. Camacho, TJDEI, 2, 88-101 (2016)

8. D. A. Norman, The design of everyday things, 217-257 (2013)

9. T. Brown, HBR, 86, 84-92 (2008)

10. J.S. Linsey, E. F. Clauss, T. Kurtoglu, J. T. Murphy, K. L. Wood, A. B. Markman, JMD, $133(2011)$

11. S. Kulkarni, J. D. Summers, N. Vargas-Hernandez, J. J. Shah, JCB, 35, 168-198 (2001)

12. M. F. Chen, C. M. Yang, W. Y. Lai, Proceedings of the SIGGRAPH ASIA Symposium on Education (2016) 